УДК 656. 212. 5

Канд. техн. наук М.Ю. Куценко

\title{
ДОСЛІДЖЕННЯ ДИНАМІЧНИХ ТА ЕНЕРГЕТИЧНИХ ХАРАКТЕРИСТИК ПОЛОГО-СХІДЧАСТОГО ПОЗДОВЖНЬОГО ПРОФІЛЮ СОРТУВАЛЬНИХ ГІРОК
}

\section{Представив д-р техн. нак, професор С.С. Альошинський}

Вступ. При розробленні проектної документації сортувального пристрою основною задачею є вибір оптимального варіанта його конструкції i технічного оснащення. В сучасних умовах функціонування залізничного транспорту особливе місце у системі критеріїв оцінки його роботи займають економічність i якість сортувального процесу. Конструктивні параметри переважної більшості існуючих вітчизняних сортувальних гірок були отримані в середині минулого сторіччя. Варто зазначити, що відомі на той час методики їх розрахунку були спрямовані на інтенсифікацію сортувального процесу для забезпечення переробки зростаючих обсягів вагонопотоків. Крім того, тогочасний парк вантажних вагонів відрізнявся своїми ходовими якостями від сучасного, а саме значно більшим значенням основного питомого опору руху. 
При цьому питання отримання енергоефективних конструктивних параметрів 3 метою зменшення експлуатаційних витрат не було найбільш актуальним.

Аналіз попередніх досліджень. У різні часи питанням удосконалення поздовжнього профілю сортувальних гірок займалися такі вчені, як: Є.В. Архангельський, К.С. Ахвердієв, П.В. Бартенєв, I.В. Берестов, С.А. Бессоненко, В.I. Бобровський, М.П. Божко, Є.А. Гібшман, А.М. Гуда, Ю.Т. Гурічев, М.Г. Дашков, О.М. Долаберідзе, I.В. Жуковицький, А.М. Козлов, Ю.О. Муха, Є.В. Нагорний, В.М. Образцов, О.М. Огар, В.Є. Павлов, А.3. Пестременко, А.С. Писанко, М.В. Правдін, М.О. Рогинський, В.М. Рудановський, I.I. Страковський, Л.Б. Тішков, В.П. Шейкін, А.П. Шипулін та ін.

Аналізуючи роботи [1-11], можна зазначити, що у минулому сторіччі $\mathrm{y}$ відношенні облаштування профілю гірки від вершини до останньої розділової стрілки на той час існувало два напрямки:

- перший - найбільш розповсюджений, зокрема в СРСР, - створення сприятливого для спокійного спуску вагонів профілю 3 відносно великою кількістю уклонів, що послідовно знижувалися, зі швидкісними уклонами 40 - 50\%о довжиною 50 - 60 м;

- другий - у Німеччині облаштування гірок крутим (35-65\%о) швидкісним уклоном, за яким проміжний уклон (13-15\%) переходив у горизонтальну площадку.

Діючі в Україні Правила та норми проектування сортувальних пристроїв (ПНПСП) [1] висувають такі вимоги щодо профілю спускної частини сортувальних гірок.

Швидкісний елемент спускної частини гірки проектується найбільш крутим (до 50 \%о) для отримання потрібних інтервалів на вершині гірки при вільному скочуванні відчепів. Що стосується нижнього обмеження крутизни швидкісної ділянки, то бажано, щоб вона була не менше 40 \% на гірках великої і підвищеної потужності, 30-40 \%о на гірках середньої потужності і 25-30\% на гірках малої потужності. Різниця крутизни швидкісного елемента і наступного за ним допускається не більше $25 \%$.

Перша гальмова позиція гірок підвищеної, великої і середньої потужностей необхідно розміщувати на спуску крутизною не менше $12 \%$, а на гірках малої потужності (з однією гальмовою позицією на спускній частині) більше 7 \%о.

Другу гальмову позицію необхідно проектувати на спуску крутизною, що забезпечує в несприятливих умовах рушання 3 місця розрахункових поганих бігунів, але не менше $7 \%$, а в холодних температурних зонах - не менше $10 \%$. За умовами мінімізації потужності паркової гальмової позиції стрілочна зона має розташовуватися на неприскорюючому уклоні.

Крутизна ділянки стрілочної зони повинна проектуватися в межах від 1 до $1,5 \%$, у крайніх пучках - до $2 \%$ для гірок 3 кількістю колій до 30 і до 2,5 \%о для гірок 3 кількістю колій більше 30 і в холодних температурних зонах.

Паркова гальмова позиція при обладнанні ㄲi у уповільнювачами i розташуванні в кривій проектується на уклоні до 2 \%о, на прямій - до 1,5\%о.

Сортувальні колії також мають розташовуватися на неприскорюючому уклоні. Їх слід проектувати на рівномірному спуску крутизною 0,6 \%о.

Слід зазначити, що на сьогодні багатьма вченими продовжуються пошуки оптимального поздовжнього профілю сортувальних гірок.

Мета статті. Метою даної статті $\epsilon$ дослідження динамічних та енергетичних характеристик полого-східчастого поздовжнього профілю сортувальних гірок у порівнянні з поздовжнім профілем, який рекомендований ПНПСП. 
Основна частина. Автором були проведені експериментальні дослідження, метою яких був розрахунок конструктивних параметрів сортувальних гірок для типових гіркових горловин за методикою, запропонованою в [1], 3 подальшим імітаційним моделюванням процесу скочування бігунів. За імітаційну модель було обрано модель, розроблену у [12].

3 метою всебічного характеру дослідження було обрано типові гіркові горловини, що рекомендовані до застосування відповідно на гірках малої потужності (ГМП), гірках середньої та великої потужності (ГСП та ГВП) [13]:

- на 8 колій 3 єдиною парковою гальмовою позицією (ПГП) та 3 однією гальмовою позицією (ГП) на спускній частині (відповідно 1 та 2 варіант);

- на 24 колії (3 варіант);
- дві горловини на 32 колії з розміщенням 1 ГП до та після першої розділової стрілки (відповідно 4 та 5 варіант).

Дослідження проводилися при таких вихідних умовах:

- оскільки дані про структуру вагонопотоку відсутні, то, згідно з [1], за розрахункову приймається легка вагова категорія 3 вагою розрахункового бігуна $245,25 \mathrm{KH}$;

- вітер зустрічний зі швидкістю 3 м/с;

- розрахункова температура - $10^{\circ} \mathrm{C}$;

- кут між напрямком вітру та віссю дільниці колії, по якій рухається відчеп, дорівнює $20^{\circ}$;

- решта умов приймається 3 відповідних таблиць [1].

За результатами імітаційного моделювання побудована узагальнена табл. 1 та діаграма щодо пробігу розрахункового бігуна до розрахункової точки за відповідними варіантами (рис. 1).

Таблиця 1

Узагальнені результати імітаційного моделювання

\begin{tabular}{|c|c|c|c|c|c|c|c|c|c|c|c|c|}
\hline \multirow{2}{*}{ 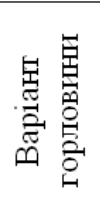 } & \multirow{2}{*}{$\begin{array}{c}T_{0}^{\max }, \\
\mathrm{c}\end{array}$} & \multirow{2}{*}{$\begin{array}{c}H_{p}, \\
\mathbf{M}\end{array}$} & \multirow{2}{*}{$\begin{array}{c}L_{p} / \\
L_{n p}^{P E}, \mathrm{M}\end{array}$} & \multicolumn{2}{|c|}{$V_{B x}^{I I \Pi}, \mathrm{M} / \mathrm{c}$} & \multirow{2}{*}{$\begin{array}{c}\begin{array}{c}h_{\text {гал }}^{I I I}, \\
\mathrm{\kappa} \text { Дж/кH }\end{array} \\
\mathrm{XX}(\mathrm{X})\end{array}$} & \multicolumn{2}{|c|}{$V_{B X}^{I I I \Pi I}, \mathrm{M} / \mathrm{c}$} & \multirow{2}{*}{$\begin{array}{c}\begin{array}{c}h_{\text {zas }}^{\text {IIII }}, \\
\text { кДж/кH }\end{array} \\
\text { ДX }(\mathrm{X})\end{array}$} & \multicolumn{2}{|c|}{$V_{B x}^{\Pi \Pi \Pi I}, \mathrm{M} / \mathrm{c}$} & \multirow{2}{*}{ 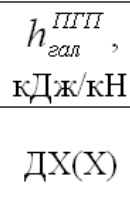 } \\
\hline & & & & $\begin{array}{l}\text { дх } \\
\text { (x) }\end{array}$ & ДП & & $\begin{array}{l}\text { ДХ } \\
(\mathrm{X})\end{array}$ & ДП & & $\begin{array}{l}\text { ДХ } \\
(\mathrm{X})\end{array}$ & ДП & \\
\hline 1 & 17,50 & 1,33 & $\begin{array}{c}282,11 / \\
228,65\end{array}$ & - & - & - & - & - & - & 3,42 & 0,74 & 0,474 \\
\hline 2 & 11,70 & 1,43 & $\begin{array}{c}282,11 / \\
244,87\end{array}$ & 4,08 & 3,83 & 0,484 & - & - & - & 2,70 & 1,64 & 0,278 \\
\hline 3 & 10,00 & 3,18 & $\begin{array}{c}441,15 / \\
458,82 \\
\end{array}$ & 5,02 & 4,61 & - & 6,44 & 5,09 & 1,905 & 3,09 & 2,65 & 0,403 \\
\hline 4 & 8,23 & 3,66 & $\begin{array}{c}441,80 / \\
509,05\end{array}$ & 5,43 & 4,99 & 0,030 & 7,22 & 5,92 & 2,116 & 3,98 & 3,52 & 0,735 \\
\hline 5 & 8,23 & 3,83 & $\begin{array}{c}429,85 / \\
491,31\end{array}$ & 6,75 & 5,95 & 0,048 & 7,27 & 6,01 & 2,082 & 3,86 & 3,44 & 0,686 \\
\hline
\end{tabular}

3 цих даних очевидно, що для обох ГМП (варіанти 1,2) пробіг розрахункового бігуна до розрахункової точки у несприятливих умовах не забезпечується, а отже, згідно 3 [1], дані сортувальні гірки не відповідають вимогам безпеки скочування вагонів та безперебійності виробничого процесу. Натомість, у варіантах 3-5 спостерігається перепробіг розрахункового бігуна. Це пояснюється завищеною висотою гірки, що, в свою чергу, призводить до збільшення витрат на гальмування дуже хорошого бігуна у процесі скочування та не сприяє 
ресурсозбереженню. Між тим потужність 1 ГП на умову забезпечення необхідних інтервалів на розділових елементах та допустимої швидкості входу на 2 ГП використовується тільки у 4 та 5 варіантах та складає лише 0,029 та 0,048 кДж/кН відповідно.

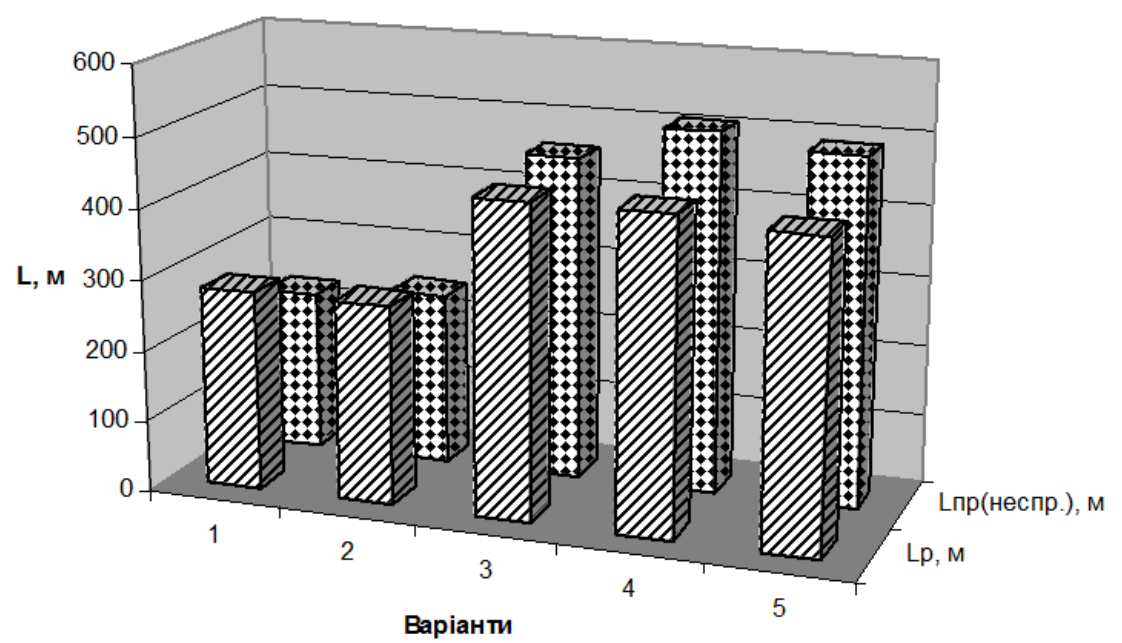

\begin{tabular}{|l|c|c|c|c|c|}
\hline Варіанти & 1 & 2 & 3 & 4 & 5 \\
\hline ㄴp, м & 282,11 & 282,11 & 441,15 & 441,8 & 429,85 \\
\hline ■ Lпр(неспр.), м & 228,65 & 244,87 & 458,82 & 509,05 & 491,31 \\
\hline
\end{tabular}

Рис. 1. Результати імітаційного моделювання щодо пробігу розрахункового бігуна до розрахункової точки за варіантами

Вищенаведене свідчить про те, що розрахункова висота та поздовжній профіль, які були отримані за методикою [1], не є оптимальними; в деяких випадках це призводить до необгрунтовано завищених та нераціонально застосованих енерговитрат, якими супроводжується сортувальний процес, а в деяких до неможливості забезпечення його безпеки та безперебійності.

Розроблене у [12] програмне забезпечення дозволило провести комплексний розрахунок щодо визначення оптимального поздовжнього профілю сортувальних гірок виходячи з мінімізації потрібної потужності уповільнювачів спускної частини.

Результати розрахунків наведені у табл. 2 і на рис. 2-6, що подані у вигляді порівняння рекомендованих конструк- тивних параметрів 3 тими, що були отримані за методикою ПНПСП.

Аналіз результатів проведених розрахунків свідчить про таке:

- конструктивні параметри сортувальних пристроїв, отримані згідно із запропонованою процедурою їх комплексного розрахунку, на відміну від тих, що були визначені згідно з вимогами ПНПСП, характеризуються полого-східчастим поздовжнім профілем спускної частини;

- враховуючи встановлену у [12] незначну залежність потрібної потужності ПГП від зміни уклону стрілочної зони (до 5,8 \%), проектування відповідної дільниці виконувалося на максимально допустимому уклоні 2 \%, наслідком чого стало зменшення профільної висоти дільниці від вершини гірки до початку стрілочної зони, що, відповідно, призвело 


\section{Експлуатація залізниць}

до зменшення потрібної потужності розташованих на ній уповільнювачів;

- для ГМП з єдиною ПГП (1 варіант) забезпечення умови докочування розрахункового бігуна до розрахункової точки в зимових несприятливих умовах стало можливим внаслідок збільшення висоти сортувальної гірки на $18 \%$ (рис. 2). При цьому потрібна потужність єдиної ПГП збільшилася на 19,4%;

- використання полого-східчастого типу профілю для ГМП 3 однією гальмовою позицією на спускній частині (2 варіант, рис. 3) дозволило забезпечити виконання вимоги щодо безпеки та безперебійності сортувального процесу та залишити висоту сортувальної гірки незмінною (1,43 м). Незмінною залишилася сумарна потрібна потужність гальмової позиції спускної частини (1,280 кДж/кН);

- застосування рекомендованого поздовжнього профілю спускної частини дозволило зменшити висоту для ГСП (3 варіант, рис. 4) та обох варіантів ГВП (4 варіант рис. 5 і 5 варіант рис. 6) відповідно на 21,8, 33,1 та 30,1 \%. При цьому сумарна потрібна потужність гальмових позицій спускної частини зменшилася на 26,7, 39,8 та 36,1% відповідно.

Таблиця 2

Базисний та рекомендований варіанти конструктивного виконання поздовжнього профілю сортувальних гірок

\begin{tabular}{|c|c|c|c|c|c|c|c|c|c|c|c|}
\hline 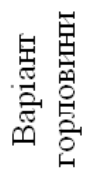 & $\begin{array}{c}\text { Варіант } \\
\text { профіпю }\end{array}$ & $\begin{array}{l}i_{\text {wus } 1}, \\
\% 0\end{array}$ & $\begin{array}{l}i_{\text {wB } 2_{2}}, \\
\% 0\end{array}$ & $\begin{array}{l}i_{\text {uus } 3}, \\
\% 0\end{array}$ & $\begin{array}{c}i_{1 T \Pi}, \\
\% 0\end{array}$ & $\begin{array}{l}i_{n p}, \\
\% 0\end{array}$ & $\begin{array}{c}i_{2 T I} \\
\%\end{array}$ & $\begin{array}{l}i_{c 3}, \\
\% 0\end{array}$ & $\begin{array}{c}i_{\Pi \Gamma \Pi}, \\
\% 0\end{array}$ & $\begin{array}{c}i_{P T}, \\
\% 0\end{array}$ & $\begin{array}{c}H_{p} \\
\mathbf{M}\end{array}$ \\
\hline \multirow{2}{*}{1} & ПНПСП & 26,2 & 7,0 & - & - & - & - & 2,0 & 1,5 & 0,6 & 1,33 \\
\hline & рекоменд. & 19,9 & 22,7 & - & - & - & - & 2,0 & 1,5 & 0,6 & 1,57 \\
\hline \multirow{2}{*}{2} & ПНПСП & 30,6 & - & - & 7,0 & - & $\begin{array}{llll}- & \\
\end{array}$ & 2,0 & 1,5 & 0,6 & 1,43 \\
\hline & рекоменд. & 19,2 & - & $\begin{array}{lll}- \\
-\end{array}$ & 21,4 & - & - & 2,0 & 1,5 & 0,6 & 1,43 \\
\hline \multirow{2}{*}{3} & ПНПСП & 44,8 & - & - & 19,8 & 7,0 & 7,0 & 2,0 & 1,5 & 0,6 & 3,18 \\
\hline & рекоменд. & 29,7 & - & - & 7,0 & 3,1 & 25,3 & 2,0 & 1,5 & 0,6 & 2,61 \\
\hline \multirow{2}{*}{4} & ПНПСП & 50,0 & - & - & 25,0 & 8,0 & 7,0 & 2,0 & 1,5 & 0,6 & 3,66 \\
\hline & рекоменд. & 33,1 & - & - & 7,2 & 2,4 & 25,7 & 2,0 & 1,5 & 0,6 & 2,75 \\
\hline \multirow{2}{*}{5} & ПНПСП & 50,0 & 25,0 & 21,2 & 12,0 & 7,0 & 7,0 & 2,0 & 1,5 & 0,6 & 3,83 \\
\hline & рекоменд. & 31,2 & 30,9 & 12,9 & 7,1 & 1,6 & 13,1 & 2,0 & 1,5 & 0,6 & 2,94 \\
\hline
\end{tabular}

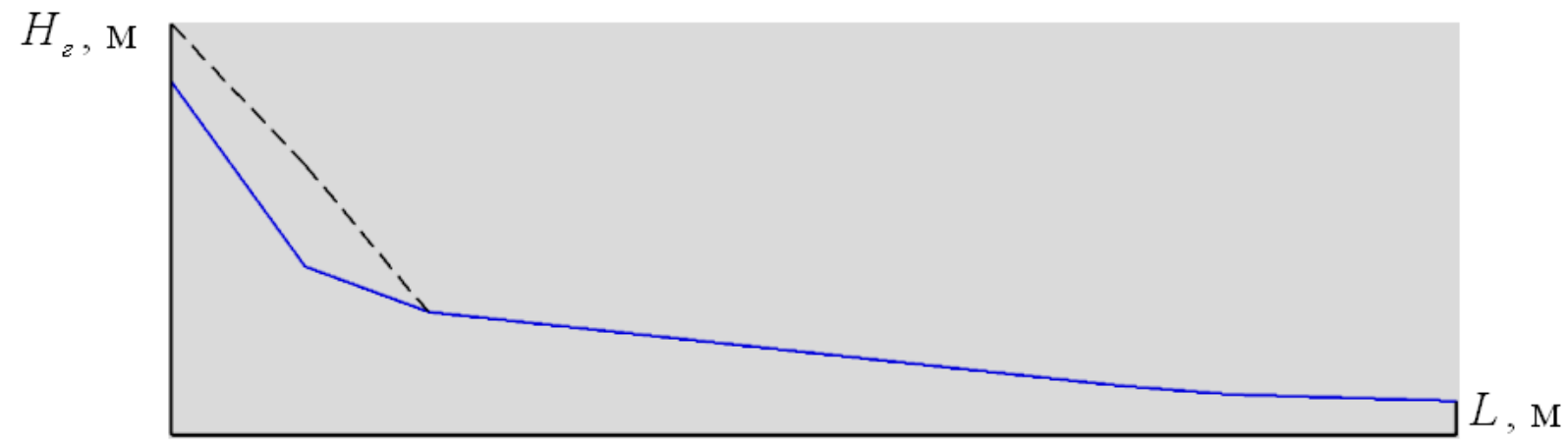

Рис. 2. Конструктивні параметри ГМП з єдиною ПГП, рекомендовані ПНПСП (суцільна лінія) та отримані за результатами їх комплексного розрахунку (штрихова лінія) 


\section{Експлуатація залізниць}

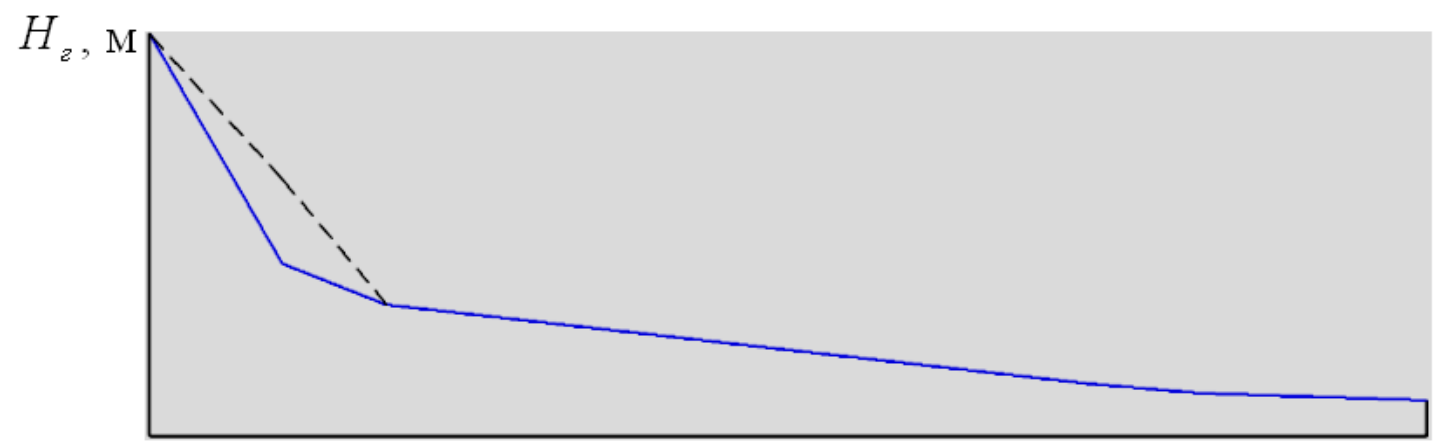

$L, \mathrm{M}$

Рис. 3. Конструктивні параметри ГМП з 1 гальмовою позицією на спускній частині рекомендовані ПНПСП (суцільна лінія) та отримані за результатами їх комплексного розрахунку (штрихова лінія)

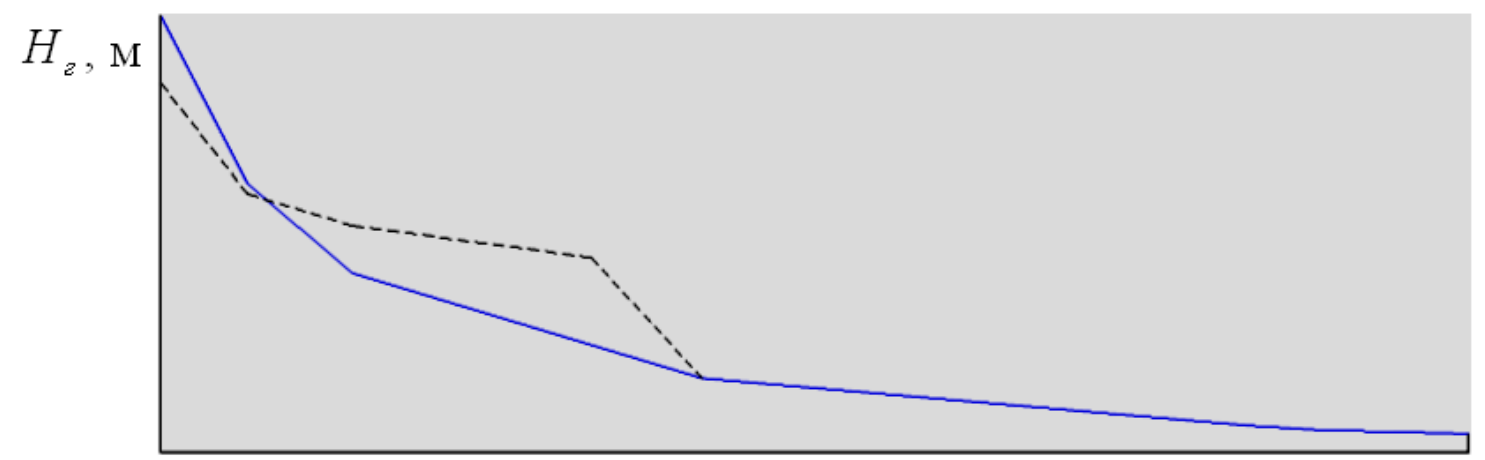

$L, \mathrm{M}$

Рис. 4. Конструктивні параметри ГСП, рекомендовані ПНПСП (суцільна лінія) та отримані за результатами їх комплексного розрахунку (штрихова лінія)

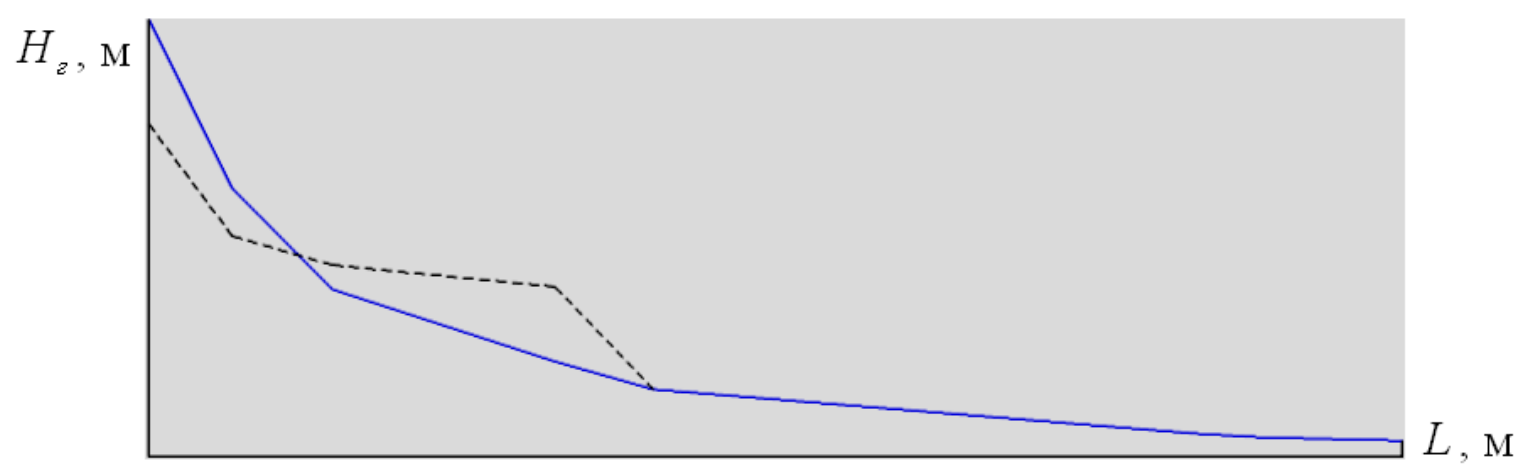

Рис. 5. Конструктивні параметри ГВП з розташуванням 1 ГП до 1-ї розділової стрілки, рекомендовані ПНПСП (суцільна лінія) та отримані за результатами їх комплексного розрахунку (штрихова лінія) 


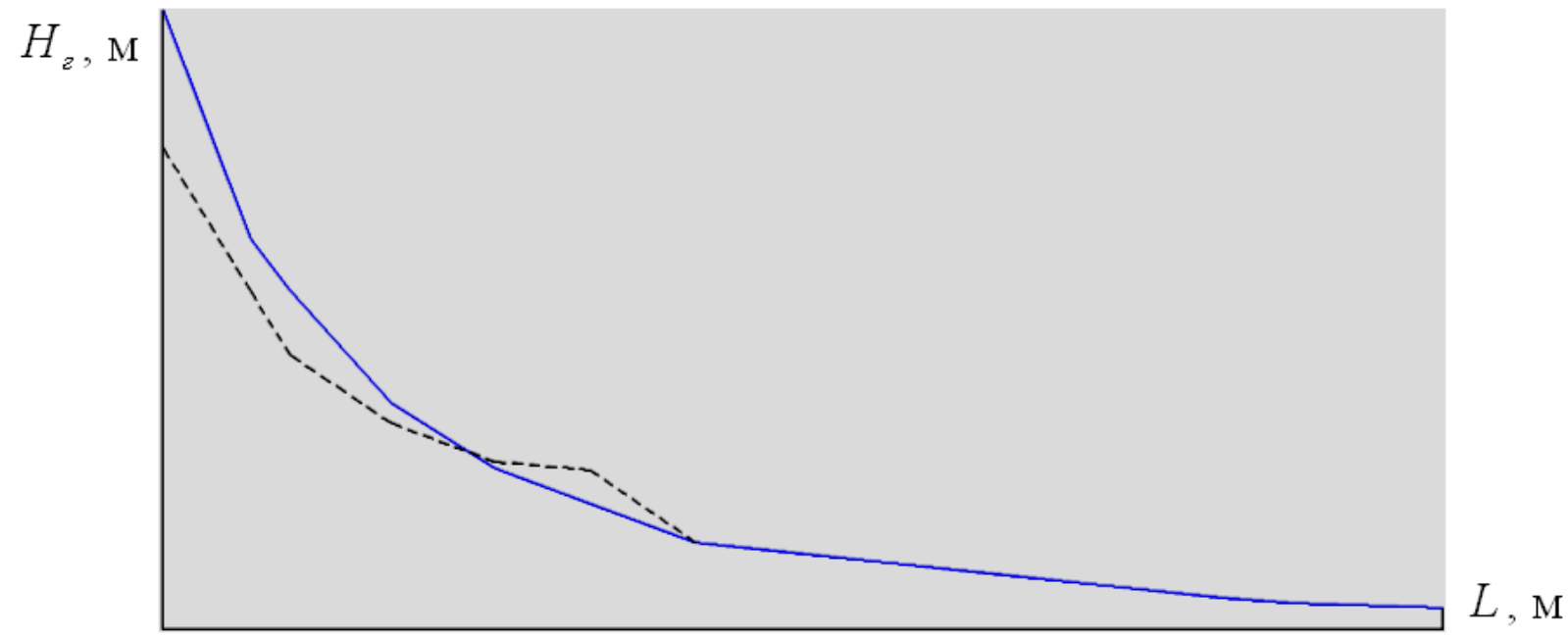

Рис. 6. Конструктивні параметри ГВП з розташуванням 1 ГП після 1-ї розділової стрілки, рекомендовані ПНПСП (суцільна лінія) та отримані за результатами їх комплексного розрахунку (штрихова лінія)

Вищенаведені результати відносно зміни величини сумарної потрібної потужності гальмових позицій спускної частини при застосуванні рекомендованого типу поздовжнього профілю у випадках варіантів 3-5 свідчать про доцільність його застосування. Результати, отримані для ГМП 3 єдиною ПГП (1 варіант), попри збільшення висоти гірки та потрібної потужності ПГП, також $є$ такими, що дозволяють рекомендувати до застосування полого-східчастий тип поздовжнього профілю, який у даному випадку забезпечує виконання умови стосовно безпеки та безперебійності сортувального процесу.

Отримані вище конструктивні параметри сортувальних гірок визначалися 3 одночасним проведенням імітаційного моделювання процесу скочування розрахункових бігунів та перевіркою їх на забезпечення пробігу розрахункового бігуна в зимових несприятливих умовах до розрахункової точки.

Результати імітаційного моделювання процесу скочування розрахункових бігунів при поздовжньому профілі ПНПСП та полого-східчастому профілі наведені відповідно в табл. 3 та 4. Аналіз отриманих результатів дозволяє зробити такі висновки.
Пробіг розрахункового бігуна до розрахункової точки в зимових несприятливих умовах скочування забезпечується в усіх випадках у повній мірі.

Висота сортувальних пристроїв та конструкції їх поздовжнього профілю задовольняють вимоги забезпечення можливості реалізації встановленої швидкості розпуску в усіх випадках.

У 1 варіанті (ГМП з єдиною ПГП), внаслідок зміни конструктивних параметрів (збільшення висоти гірки та застосування полого-східчастого поздовжнього профілю спускної частини), величина гальмування хорошого бігуна (ХБ) на ПГП за умови виходу 3 неї 3 допустимою швидкістю збільшилася як в несприятливих, так i сприятливих умовах скочування на величину 56,2 та 18,5 \% відповідно. В той же час, потрібна потужність ПГП, яка повинна забезпечити зупинку дуже хорошого бігуна (ДХБ) у літніх сприятливих умовах та $\epsilon$ вирішальною при виборі остаточної потрібної потужності та кількості уповільнювачів, збільшилася не дуже суттєво - на 16,2 \%. Обгрунтуванням для застосування таких конструктивних параметрів даної ГМП служить забезпечення виконання вимоги стосовно безпеки та безперебійності сортувального процесу. 
Таблиця 3

Результати імітаційного моделювання скочування розрахункових бігунів (поздовжній профіль ПНПСП)

\begin{tabular}{|c|c|c|c|c|c|c|c|c|c|c|c|c|c|c|c|c|}
\hline \multirow{2}{*}{ 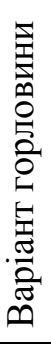 } & \multirow[b]{2}{*}{$T_{0}^{\max }, \mathrm{c}$} & \multirow{2}{*}{$\begin{array}{c}H_{p}, \\
\mathbf{M}\end{array}$} & \multirow[b]{2}{*}{$L_{p}, \mathrm{M}$} & \multirow{2}{*}{ 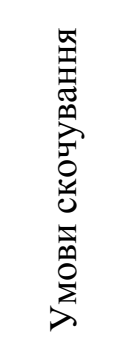 } & \multirow{2}{*}{$L_{n p}^{P Б}, \mathrm{M}$} & \multicolumn{2}{|c|}{$V_{\theta x}^{1 \Gamma \Pi}, \mathrm{M} / \mathrm{c}$} & \multirow{2}{*}{$\begin{array}{c}h_{\text {гал }}^{1 Г п ~} \\
\text { кДж/ } \\
\text { кН } \\
\text { ДХ(X } \\
\text { ) }\end{array}$} & \multicolumn{2}{|c|}{$V_{B x}^{2 \Gamma \Pi}, \mathrm{M} / \mathrm{c}$} & \multirow{2}{*}{$\begin{array}{c}h_{\text {гал }}^{2 Г п}, \\
\text { кДж/ } \\
\text { кН } \\
\\
\text { ДХ(X) }\end{array}$} & \multicolumn{2}{|c|}{$V_{B x}^{\Pi Г \Pi}, \mathrm{M} / \mathrm{c}$} & \multirow{2}{*}{ 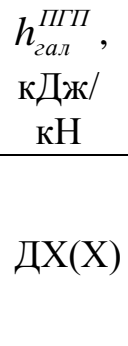 } & \multirow{2}{*}{$\begin{array}{c}h_{\text {зуn }}, \\
\text { кДж/ } \\
\text { кН } \\
\\
\text { ДX(X) }\end{array}$} & \multirow{2}{*}{$\begin{array}{c}H_{m c y}, \\
\text { кДж/ } \\
\kappa \mathrm{H}\end{array}$} \\
\hline & & & & & & $\begin{array}{c}\text { ДХ(X } \\
)\end{array}$ & ДП & & $\begin{array}{c}\text { ДХ(X } \\
)\end{array}$ & ДП & & $\begin{array}{l}\text { ДХ( } \\
\mathrm{X})\end{array}$ & ДП & & & \\
\hline \multirow{2}{*}{1} & \multirow{2}{*}{17,50} & \multirow{2}{*}{1,33} & \multirow{2}{*}{$\begin{array}{c}282,1 \\
1\end{array}$} & неспр & $\begin{array}{c}228,6 \\
5\end{array}$ & - & - & - & - & - & - & 3,42 & 0,74 & 0,474 & \multirow{2}{*}{1,173} & \multirow{2}{*}{1,370} \\
\hline & & & & $\begin{array}{c}\text { сприят } \\
\text {. }\end{array}$ & $\begin{array}{c}316,2 \\
9\end{array}$ & - & - & - & - & - & - & 4,58 & 2,70 & 1,007 & & \\
\hline \multirow{2}{*}{2} & \multirow{2}{*}{11,70} & \multirow{2}{*}{1,43} & \multirow{2}{*}{$\begin{array}{c}282,1 \\
1\end{array}$} & неспр & $\begin{array}{c}244,8 \\
7\end{array}$ & 4,08 & 3,83 & 0,484 & - & - & - & 2,70 & 1,64 & 0,278 & \multirow{2}{*}{0,647} & \multirow{2}{*}{1,280} \\
\hline & & & & $\begin{array}{c}\text { сприят } \\
\text {. }\end{array}$ & $\begin{array}{c}358,9 \\
5\end{array}$ & 4,33 & 4,14 & 0,772 & - & - & - & 3,29 & 3,22 & 0,481 & & \\
\hline \multirow{2}{*}{3} & \multirow{2}{*}{10,00} & \multirow{2}{*}{3,18} & \multirow{2}{*}{$\begin{array}{l}441,1 \\
5\end{array}$} & неспр & $\begin{array}{c}458,8 \\
2\end{array}$ & 5,02 & 4,61 & - & 6,44 & 5,09 & 1,905 & 3,09 & 2,65 & 0,403 & \multirow{2}{*}{2,573} & \multirow{2}{*}{3,230} \\
\hline & & & & сприят & $\begin{array}{c}672,3 \\
3\end{array}$ & 5,05 & 4,71 & - & 6,64 & 5,70 & 2,019 & 3,47 & 4,62 & 0,545 & & \\
\hline \multirow{2}{*}{4} & \multirow{2}{*}{8,23} & \multirow{2}{*}{3,66} & 441,8 & неспр & $\begin{array}{c}509,0 \\
5\end{array}$ & 5,43 & 4,99 & 0,030 & 7,22 & 5,92 & 2,116 & 3,98 & 3,52 & 0,735 & & \\
\hline & & & 0 & сприят & $\begin{array}{c}778,2 \\
6\end{array}$ & 5,46 & 5,09 & - & 7,42 & 6,51 & 2,147 & 4,47 & 5,37 & 0,961 & 3,097 & 3,830 \\
\hline & & & 429.8 & неспр & $\begin{array}{c}491,3 \\
1\end{array}$ & 6,75 & 5,95 & 0,048 & 7,27 & 6,01 & 2,082 & 3,86 & 3,44 & 0,686 & & \\
\hline 5 & $8,2 J$ & 3,83 & 5 & $\begin{array}{c}\text { сприя } \\
\text { т. }\end{array}$ & $\begin{array}{c}736,7 \\
2\end{array}$ & 6,82 & $\begin{array}{r}6, \\
24\end{array}$ & - & 7,49 & 6,60 & $\begin{array}{l}2,1 \\
59\end{array}$ & $\begin{array}{l}4,2 \\
6\end{array}$ & 5,18 & 0,866 & 3,121 & 4,070 \\
\hline
\end{tabular}


Таблиця 4

Результати імітаційного моделювання скочування розрахункових бігунів (рекомендований варіант профілю)

\begin{tabular}{|c|c|c|c|c|c|c|c|c|c|c|c|c|c|c|c|c|}
\hline \multirow{2}{*}{ 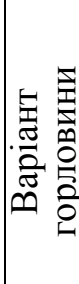 } & \multirow{2}{*}{$\begin{array}{c}T_{0}^{\max }, \\
\quad \mathrm{c}\end{array}$} & \multirow{2}{*}{$\begin{array}{c}H_{p}, \\
\mathbf{M}\end{array}$} & \multirow{2}{*}{$L_{p}, \mathrm{M}$} & \multirow{2}{*}{ 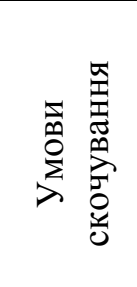 } & \multirow{2}{*}{$\begin{array}{c}L_{n p}^{P Б} \\
\mathbf{M}\end{array}$} & \multicolumn{2}{|c|}{$V_{B x}^{1 \Gamma \Pi}, \mathrm{M} / \mathrm{c}$} & \multirow{2}{*}{$\begin{array}{c}h_{\text {гал }}^{1 \text { гп }} \\
\text { кДж/ } \\
\text { кН } \\
\text { ДХ(X } \\
\quad)\end{array}$} & \multicolumn{2}{|c|}{$V_{B x}^{2 \Gamma \Pi}, \mathrm{M} / \mathrm{c}$} & \multirow{2}{*}{$\begin{array}{c}h_{\text {гал }}^{2 Г п ~} \\
\text { кДж/ } \\
\text { кН } \\
\text { ДХ(X) }\end{array}$} & \multicolumn{2}{|c|}{$V_{B x}^{\Pi \Gamma \Pi}, \mathrm{M} / \mathrm{c}$} & \multirow{2}{*}{ 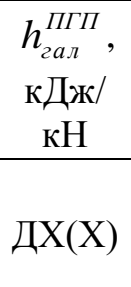 } & \multirow{2}{*}{$\begin{array}{c}h_{\text {зуn }}, \\
\text { кДж/ } \\
\text { кН } \\
\text { ДX }(\mathrm{X})\end{array}$} & \multirow{2}{*}{$\begin{array}{c}H_{m c 4}, \\
\text { кДж/ } \\
\kappa \mathrm{H}\end{array}$} \\
\hline & & & & & & $\begin{array}{c}\text { ДХ(X } \\
)\end{array}$ & ДП & & $\begin{array}{c}\text { ДХ(X } \\
\quad)\end{array}$ & ДП & & $\begin{array}{c}\text { ДХ(X } \\
)^{\prime}\end{array}$ & ДП & & & \\
\hline \multirow{2}{*}{1} & \multirow{2}{*}{17,50} & \multirow{2}{*}{1,57} & \multirow{2}{*}{$\begin{array}{c}282,1 \\
1\end{array}$} & неспр & 282,11 & - & - & - & - & - & - & 4,76 & $\begin{array}{c}2,3 \\
2\end{array}$ & 1,082 & \multirow{2}{*}{1,400} & \multirow{2}{*}{1,660} \\
\hline & & & & сприят. & 375,91 & - & - & - & - & - & - & 5,03 & $\begin{array}{c}3,4 \\
0\end{array}$ & 1,235 & & \\
\hline \multirow{2}{*}{2} & \multirow{2}{*}{11,70} & \multirow{2}{*}{1,43} & \multirow{2}{*}{$\begin{array}{c}282,1 \\
1\end{array}$} & неспр & 282,11 & 3,22 & 2,66 & 0,819 & - & - & - & 3,09 & $\begin{array}{c}2,3 \\
2\end{array}$ & 0,406 & \multirow{2}{*}{0,630} & \multirow{2}{*}{1,280} \\
\hline & & & & сприят. & 376,69 & 3,26 & 2,80 & 0,862 & - & - & - & 3,25 & $\begin{array}{c}3,4 \\
1\end{array}$ & 0,464 & & \\
\hline \multirow{2}{*}{3} & \multirow{2}{*}{10,00} & \multirow{2}{*}{2,61} & \multirow{2}{*}{$\begin{array}{c}441,1 \\
5\end{array}$} & неспр & 441,15 & 3,35 & 2,88 & 0,583 & 3,03 & $\begin{array}{c}2,5 \\
5\end{array}$ & 0,955 & 3,06 & $\begin{array}{c}1,7 \\
7\end{array}$ & 0,393 & \multirow{2}{*}{1,728} & \multirow{2}{*}{2,550} \\
\hline & & & & сприят. & 567,45 & 3,38 & 2,99 & 0,384 & 3,77 & $\begin{array}{c}3,2 \\
8\end{array}$ & 1,239 & 3,32 & $\begin{array}{c}3,7 \\
3\end{array}$ & 0,490 & & \\
\hline \multirow{2}{*}{4} & \multirow{2}{*}{8,23} & \multirow{2}{*}{2,75} & 441,8 & неспр & 441,80 & 3,96 & 3,50 & 0,705 & 3,50 & $\begin{array}{c}3,2 \\
6\end{array}$ & 0,863 & 3,72 & $\begin{array}{c}2,2 \\
2\end{array}$ & 0,631 & & \\
\hline & & & 0 & сприят. & 604,94 & 3,99 & 3,61 & 0,496 & 4,16 & $\begin{array}{c}3,8 \\
9\end{array}$ & 1,051 & 4,12 & $\begin{array}{c}4,0 \\
6\end{array}$ & 0,805 & 1,813 & 2,740 \\
\hline 5 & 823 & 204 & 429,8 & неспр & 429,85 & 5,52 & 4,69 & 0,935 & 4,32 & $\begin{array}{c}4,4 \\
8\end{array}$ & 0,682 & 3,59 & $\begin{array}{c}2,2 \\
3\end{array}$ & 0,583 & 1605 & 2000 \\
\hline 5 & $8,2 J$ & 2,94 & 5 & сприят. & 590,35 & 5,59 & 4,95 & 0,708 & 4,93 & $\begin{array}{c}5,0 \\
6\end{array}$ & 0,886 & 3,99 & $\begin{array}{c}4,0 \\
4\end{array}$ & 0,752 & 1,093 & 2,990 \\
\hline
\end{tabular}


У 2 варіанті (ГМП 3 однією гальмовою позицією на спускній частині) при використанні рекомендованого типу поздовжнього профілю спостерігається збільшення необхідної величини гальмування ХБ на I ГП на 40,9 та 10,4 \% відповідно в несприятливих та сприятливих умовах скочування. Зважаючи на те, що остаточна потужність цієї ГП має визначатися в сприятливих умовах, то отримана зміна необхідної потужності гальмування $(10,4 \%)$ не $є$ значною. Потрібна величина гальмування ХБ на ПГП у несприятливих умовах збільшилася на $31,5 \%$, а у сприятливих зменшилася на $3,5 \%$, при цьому потрібна потужність для забезпечення зупинки ДХБ у літніх сприятливих умовах зменшилася на 2,6 \%.

У 3-5 варіантах потрібна величина гальмування ХБ (для ГСП) та ДХБ (для ГВП) на І ГП для забезпечення допустимої швидкості входу на II ГП та вимог інтервального регулювання швидкості скочування вагонів була значно збільшена в усіх випадках як в несприятливих, так i сприятливих умовах скочування. Однак, зважаючи на те, що за умови застосування поздовжнього профілю, отриманого згідно 3 вимогами ПНПСП, величина необхідного гальмування на 1 ГП перебувала в межах від 0,0 до 0,048 кДж/кН (що свідчить про нераціональне використання потужності 1 ГП), вищезгадане іiі збільшення є цілком обгрунтованим. Натомість, необхідна величина гальмування на 2 ГП для забезпечення допустимої швидкості входу на ПГП та вимог інтервального регулювання швидкості скочування вагонів у цих варіантах була зменшена в несприятливих (відповідно на 49,9, 59,2 та
$67,2 \%)$ та сприятливих умовах скочування (відповідно на 38,6, 51,1 та 59 \%). Крім того, необхідна величина гальмування на ПГП для забезпечення допустимої швидкості виходу бігунів також була зменшена як у несприятливих (на 2,5, 14,2 та $15 \%$ відповідно), так і сприятливих умовах (на 10,1, 16,2 та 13,2 \% відповідно).

На відміну від конструктивних параметрів, отриманих згідно 3 вимогами ПНПСП, необхідна величина гальмування на 2 ГП для забезпечення в ії кінці зупинки ДХБ у літніх сприятливих умовах скочування для 3-5 варіантів була зменшена на величину $32,8,41,5$ та 45,7\% відповідно.

Висновки. Проведені комплексні розрахунки конструктивних параметрів для типових гіркових горловин дозволили рекомендувати як оптимальний пологосхідчастий тип поздовжнього профілю спускної частини. Результати імітаційного моделювання процесу скочування розрахункових бігунів, що були отримані із застосуванням рекомендованих конструктивних параметрів сортувальних гірок, свідчать про забезпечення пробігу розрахункового бігуна до розрахункової точки в зимових несприятливих умовах скочування (що свідчить про забезпечення вимог безпеки та безперебійності сортувального процесу) та можливість реалізації встановленої швидкості розпуску в усіх випадках.

Запропоноване

виконання конструктивних параметрів сортувальних гірок забезпечує найбільш раціональне та енергоефективне використання потужності кожної з гальмових позицій.

\section{Список літератури}

1. Правила и нормы проектирования сортировочных устройств на железных дорогах СССР [Текст] // ВСН 207-89 / МПС. - Нормативное производственно-практическое издание. - М.: Транспорт, 1992. - 104 с.

2. Образцов, В. Н. Станции и узлы. [Текст] / В.Н. Образцов. - М.: Трансжелдориздат, 1929. - Ч. 2. -90 c. 
3. Рогинский, М.О. Механизация сортировочных горок [Текст] / М.О. Рогинский. - М.: Трансжелдориздат, 1938. - 87 с.

4. Бартенев, П.В. Станции и узлы [Текст] / П. В. Бартенев. - М.: Трансжелдориздат, 1945. - $127 \mathrm{c}$.

5. Павлов, В.Е. Брохистохрома применительно к сортировочной горке [Текст] / В.Е. Павлов // Сб. науч. трудов. - Л.: ЛИИЖТ, 1969. - № 300. - С. 76-85.

6. Нагорный, Е.В. Научные основы и разработка комплексной технологии поточной и непрерывной переработки вагонов на сортировочных станциях [Текст]: дис. ... д-ра техн. наук / Е.В. Нагорный. - Харьков, 1994. - 365 с.

7. Бессоненко, С.А. Расчет продольного профиля спускной части сортировочной горки [Текст] / С.А. Бессоненко // Проблемы перспективного развития железнодорожных станций и узлов / Труды БелИИЖТа. - Гомель, 1984. - С. 69-76.

8. Огарь, А.Н. Повышение ресурсосбережения и эффективности функционирования сортировочных горок при оптимизации продольного профиля [Текст]: дисс. ... канд. техн. наук / А.Н. Огарь. - Харьков, 2002. - 194 с.

9. Правдин, Н.В. Комплексный расчет уклонов продольного профиля спускной части и высоты сортировочной горки по вероятностным показателям [Текст] / Н.В. Правдин, С.А. Бессоненко // Транспорт: наука, техника, управление. - 2006. - № 7. - С. 12-19.

10. Огар, О.М. Аналіз і особливості конструкції гіркових горловин вітчизняних сортувальних пристроїв [Текст] / О.М. Огар, О.В. Розсоха, С.М. Светличний // Зб. наук. праць. - Харків: УкрДАЗТ, 2007. - Вип. 85. - С. 57-64.

11. Гуричев, Ю.Т. Об одном подходе к задаче нахождения оптимальных параметров горки [Текст] / Ю.Т. Гуричев, А.Н. Гуда, С.Н. Дегтярев, Н.Н. Новгородов // Микропроцессорные системы управления на железнодорожном транспорте / Труды РИИЖТа. - Ростов-на-Дону, 1984. - Вып. 54. - С. 35-38.

12. Куценко, М.Ю. Підвищення енергоефективності функціонування сортувальних пристроїв на основі комплексної оптимізації конструктивних параметрів [Текст]: дис. ... канд. техн. наук / М.Ю. Куценко. - Харків, 2009. - 268 с.

13. Конструкции и параметры стрелочных горловин автоматизированных и механизированных сортировочных горок [Текст] / под ред. А.П. Гоголева. - Л.: Гипротранссигналсвязь, 1983. - 63 с.

Ключові слова: сортувальна гірка, оптимізація конструктивних параметрів, пологосхідчастий поздовжній профіль.

\section{Анотації}

У статті проведене дослідження динамічних та енергетичних характеристик пологосхідчастого поздовжнього профілю сортувальних гірок. Результати імітаційного моделювання процесу скочування розрахункових бігунів свідчать про забезпечення вимог безпеки та безперебійності сортувального процесу. Запропонований полого-східчастий тип поздовжнього профілю дозволяє значно знизити експлуатаційні витрати на забезпечення сортувального процесу.

В статье проведено исследование динамических и энергетических характеристик полого-ступенчатого продольного профиля сортировочных горок. Результаты имитационного моделирования процесса скатывания расчетных бегунов свидетельствуют об обеспечении требований безопасности и бесперебойности сортировочного процесса. 
Предложенный полого-ступенчатый тип продольного профиля позволяет значительно снизить эксплуатационные расходы на обеспечение сортировочного процесса.

In this paper a study of dynamic and energetic characteristics of the hollow-stage longitudinal profile marshalling humps. Simulation results of the process rolling settlement runners indicate that ensuring safety and security of the sorting process. Proposed a hollow-step type longitudinal profile can significantly reduce the operational costs of providing sorting process. 